INDO GLOBAL JOURNAL OF

\title{
Engineering Arabidopsis - Specific Nonhost Resistance Mechanism in Rice for Durable and Broad Spectrum Sheath Blight Resistance against Rhizoctonia solani
}

\author{
Daraksha Parween, Eram Sultan, Kalpana Dalei, Binod Bihari Sahu * \\ Department of Life Science, National Institute of Technology, Rourkela, Odisha -769008, India
}

Address for Correspondance: Binod Bihari Sahu, Parweendaraksha8@gmail.com, sultan.eram@gmail.com, kalpanadalei2034@gmail.com, binodbiharisahu@gmail.com

\section{Keywords}

Rhizoctonia; NHR;

EMS;

Basidomycete;

Sheath Blight.

\begin{abstract}
Rice (Oryza sativa L.), is the primary staple food in many countries feeding over half of the world population. One of the greatest challenges of this time is to feed the growing population by enhancing the agricultural production. Sheath blight is one of the most devastating diseases in rice cultivation and is caused by Rhizoctonia solani which belongs to the AG-1 IA (of 13 AG groups). $R$. solani Kühn is the anamorph of the basidiomycete fungus Thanatephorus cucumeris and has a wide host range including almost all cultivated crops worldwide. Arabidopsis thaliana of Brassicaceae (mustard) family, is a nonhost to fungal infection by Rhizoctonia solani, which causes sheath blight in rice. Disease resistance in all members of a plant species to all genetic variants of non-adapted pathogen species is the most common form of plant immunity, termed as non-host resistance (NHR). Till now, many NHR genes have been identified against various pathogens. However, there is no such NHR gene(s) of Arabidopsis identified against $R$. solani. Here, we aim to find whether these identified NHR genes function for resistance against $R$. solani. We screened various wild types and mutants of Arabidopsis by detached leaf inoculation experiments to check its resistance and susceptibility. Col-0 showed resistance response to infection. Mutation by EMS in A. thaliana (Col-0) will further help in the identification of NHR gene by forward genetics, which can be employed to engineer rice cultivars to provide not only durable and broad spectrum resistance against sheath blight but also be ecofriendly. (C) 2016 iGlobal Research and Publishing Foundation. All rights reserved.
\end{abstract}

Conference Proceedings: International Conference on Advances in Plant and Microbial Biotechnology (PMB2017); JIIT, Noida: February 02-04, 2017

Indo Global Journal of Pharmaceutical Sciences( ISSN 22491023 ; CODEN- IGJPAI; NLM ID: 101610675) indexed and abstracted in EMBASE(Elsevier), SCIRUS(Elsevier),CABI, CAB Abstracts, Chemical Abstract Services(CAS), American Chemical Society(ACS), Index Copernicus, EBSCO, DOAJ, Google Scholar and many more. For further details, visit http://iglobaljournal.com 